Taking advantage of "[t]he right to post either the Author's Original (AO) or Accepted Manuscript (AM) version of the Contribution on my personal or departmental web page", and knowing that "[a]ny posting of the AM version should include a prominent statement that the article has been accepted for publication by EUP [Edinburgh University Press] in the Journal, together with a link to the EUP website for the Journal [...] updated after publication, to link directly to the article abstract page on EUP Journals Online", together with "full bibliographic details [...] (journal title, volume: issue, date, page numbers)", I attach the Accepted Manuscript version of my contribution, which was published in

'Comparative Critical Studies', Volume 17, Issue 2, June 2020

'West-East' Lyric: A Comparative Approach to Lyric History

(https://www.euppublishing.com/toc/ccs/17/2)

with the title

Eastern Poetry by Western Poets: Powys Mathers' 'Translations' of Sanskrit Erotic Lyrics by Maddalena Italia

pp. 205-224

(https://www.euppublishing.com/doi/abs/10.3366/ccs.2020.0359)

DOI number: 10.3366/ccs.2020.0359 


\title{
Eastern poetry by Western poets: Powys Mathers' 'translations' of Sanskrit erotic lyrics
}

\author{
MADDALENA ITALIA
}

[T]he erotick poetry of the Hindus [...] wants elevation of sentiment and simplicity of diction. The passion, which it pictures, is sensual, but the language refined; with some tenderness in the expression and in the thoughts. Among the most celebrated poems in this class, may be mentioned, the Chaura panchasicá comprising fifty stanzas by Chaura, and Amaru s'ataca containing twice that number by Amaru. ${ }^{1}$

In his pioneering essay 'On Sanscrit and Pracrit Poetry' (1808), Henry Thomas Colebrooke (1765-1837) lamented the lack of both 'elevation of sentiment' and 'simplicity of diction' in Sanskrit erotic poetry. Throughout the history of their modern reception and translation, these poems underwent an endless process of metamorphosis to fit with evolving poetic practices and notions of 'the lyric' - to the point of acquiring new emotional nuances, while sometimes shedding the emblematic sensuality of the Sanskrit 
originals. Contemporary Anglophone readers may be familiar with the two collections of verses mentioned by Colebrooke - Bilhaṇa's late eleventh-century Caurapañcāśikā (The fifty verses of a thief) and Amaru's seventh-century² Amaruśataka (The hundred verses of Amaru) - thanks to the translations that appear in the volume Love Lyrics of the Clay Sanskrit Library series. ${ }^{3}$ However, these English versions - which are part of an everexpanding ecosystem of translations in numerous languages, both living and dead - are not the guise in which Sanskrit erotic lyrics first appeared on the stage of World Literature.

It is this pivotal moment - the percolation of these translations from the scholarly sphere to that of non-specialist literature - that this essay will focus on. A crucial agent in the dissemination and inclusion of these poems in the canon of lyric poetry was the English poet and translator Edward Powys Mathers (1892-1939). A self-professed 'second-hand' translator of Oriental literature (mostly from French intermediary versions, though not always duly acknowledged), Powys Mathers was also the author of original verses, which he presented as translations of Oriental works. ${ }^{4}$ In spite of their unapologetically un-scholarly nature, Powys Mathers' versions were permeated by 'a very sincere love of Oriental literature in translation, and, again, of course, in translation, a fairly large acquaintance with it'. ${ }^{5}$ Nonetheless, it may strike us as paradoxical that Powys Mathers, having based his version of the Amaruśataka on a collection of French prose-poems that included second-hand translations as well as sheer forgeries, felt 
confident in claiming that 'Amaru was, from our modern point of view, one of the supreme early lyric poets of the East'. ${ }^{6}$

I have discussed Powys Mathers' English rendering of Amaru's oeuvre (under the title Amores of Amaru $)^{7}$ in a recent essay; ${ }^{8}$ in this paper I will focus, instead, on his rendering of the Caurapañcāsikā as Black Marigolds..$^{9}$ The Caurapañāasikā is a collection of fifty stanzas which share the same vasantatilakā meter, the same incipit (adyāpi, "even now"), and a similar syntactic structure marked by the presence of verbs of memory and recollection in the first person, which normally close the verse and whose direct object is the poet's mistress (or any of her attributes). The narrative plot of the Caurapañcáśikā is hardly traceable in the stanzas themselves; different versions of the legend concerning the forbidden love between a poet (allegedly, the very author Caurapañcāsikīa) and a princess accompany the fifty verses in a certain number of manuscripts. ${ }^{10}$

The primary intended contribution of this paper is to spark a discussion about the conceptual tools that we can mobilize to 'make sense' of non-scholarly translations of classical Sanskrit poems - and, more in general, of classical/Eastern poetry. My preliminary observation is that these texts - however 'un-philologically', or even fictitiously translated - demand to be taken seriously. Hence the need to peel their multiple layers of textual and contextual meanings by deploying the tools of philology (which include the search and comparison of sources, close reading, and the study of the history of composition and reception of any text). 
Examined through a philological lens, these 'amateurish' texts reveal themselves to be intertextually dense. Thus, I use the metaphor of the 'watermark' to indicate the layers of meaning that are not immediately apparent to the naked eye, but which only become manifest through an exercise of genealogical search, reconstruction and comparison of literary sources. The other image that I mobilize in my analysis is that of the 'hall of mirrors': in fact, I believe that these non-scholarly translations have the power to reflect, magnify and even distort the emotional and aesthetic dimensions of both the classical/Eastern and modern/Western literary world. This textual 'hall of mirrors' should not be simply dismissed as a 'spurious' - or at least confusing - literary landscape. On the contrary, the refractions and distortions that permeate these non-philological translations are fecund of original textual meanings, which are often instrumental in the survival of both the modern translation and the 'poetic memory' of the original.

This paper is, therefore, structured as a case study that allows me to showcase this method of analysis and interpretation. First, I will briefly outline a few significant moments of the emergence and persistent fame of Black Marigolds, showing how its popularity rests - at least in part - on a highly idiosyncratic lyrical idiom. A defining feature of this idiom is a fascination for multilingualism, whether real or pretended, which manifests itself in the poet-translator's ability to surreptitiously cross and blur boundaries between literary cultures and languages (Sanskrit, Arabic, French, English). Powys Mathers' linguistic choices often generate a sense of estrangement; this is the result 
of an attempt to mimic not the Sanskrit original, but Hippolyte Fauche's French translation, ${ }^{11}$ whose syntactic and phonetic textures often appear in watermark. With its original take on the Caurapañcāsika, Black Marigolds positioned itself within a niche yet successful genre of 'Eastern' erotic poetry, as well as in a genealogy of modern renderings of Bilhana's poem. Although gesturing to an English versified translation that antedated it by only two decades, Powys Mathers' version distanced itself from both its Anglophone predecessor (Edwin Arnold's An Indian Love-Lament) ${ }^{12}$ and the Sanskrit original to create a radically new emotional landscape.

It is to this 'Mathersian' landscape of thought and feeling that I will dedicate the second part of my article. In particular, I will focus on Powys Mathers' overwriting of the graphic sensuality of the Sanskrit original through an allusive erotic palette that blends carnal desires with lust for the exotic. Moreover, Powys Mathers lingers on the theme of death, which, though not prominent in the Sanskrit text, had already become pervasive in Arnold's version. In Black Marigolds, however, death assumes an original significance as it becomes the object of a universalist message of acceptance as well as (quite probably) a reflection on the historical moment of its writing, World War I.

Another aspect that my paper takes into consideration is that of the genre and linguistic metamorphoses that Black Marigolds underwent - metamorphoses which contributed to the poem's longevity. In such an editorial context as Mark Van Doren's pioneering Anthology of World Poetry, Black Marigolds was presented as an English- 
language incarnation of the Caurapañcassikē, with Powys Mathers, the translator, treated as the midwife attending to yet another rebirth of an old Sanskrit poem. An antithetical attitude emerged among those who were more sensitive to the radical 'newness' of Black Marigolds and saw Powys Mathers' poem not simply as a new translation but as a new poem. Throughout its publishing life, Black Marigolds has been alternatively associated either with only Bilhana, only with Powys Mathers, or with neither of the two. The latter happens, famously, in John Steinbeck's Cannery Row, where Black Marigolds is quoted extensively, yet - as expected - without any reference to its author or provenance in the text of the novel.

The question that traverses this study is: What does the transformation of the Caurapañcāsikik into a successful piece of modern(ist) lyric poetry tell us about the relationship that Western readers wished (and may still wish) to have with 'Oriental' poetry? As this case study will show, Black Marigolds is essentially a hybrid creation, which attempts to preserve (to again quote Colebrooke) the 'tenderness in the expression and in the thoughts' of the original, while effectively overwriting the 'sensual' passion that permeates the Sanskrit poem. As a second-hand translation and partial rewriting, Black Marigolds is sustained by a profound enthusiasm for Sanskrit poetry, though not by first-hand knowledge. Finally, it is a work that is founded on the creative powers of multilingualism, yet not on the kind of multilingual competence that we would expect of a translator of Sanskrit poetry. In sum, Black Marigolds succeeded in creating a new lyrical 
idiom for an old Sanskrit poem: hence, it is not - in my opinion - a betrayal of its original, but a modern avatar that granted its survival into the realm of World Poetry.

'WHOEVER THOUGHT OF SANSKRIT?': BLACK MARIGOLDS AS WORLD POETRY

\author{
Whoever thought of Sanskrit? Whoever heard of Chauras? And \\ who is E. Powys Mathers? Here is one of the most beautiful \\ poems I ever read. ${ }^{13}$
}

With these words the Italo-American poet Emanuel Carnevali hailed the recent publication of Black Marigolds, which he reviewed in 1921 for the American magazine Poetry. The phonetic, lexical and syntactic texture of Black Marigolds - although deeply idiosyncratic - elicited a strong appreciation on the part of Carnevali, who commented:

'A delightfully quaint flavor is given to the poem by the slightly ungrammatical expressions and punctuation.' The same mixture of surprise and enthusiasm characterizes the century-long history of the reception of Powys Mathers' 'translation'.

Reviewing the 1998 Norton Anthology of World Poetry, Edwin Morgan lamented the absence of 'Bilhana's super-sultry Black Marigolds', ${ }^{14}$ which he considered to be one of the gems of Mark Van Doren's 1928 Anthology of World Poetry. The latter was grandly, if 
somewhat vaguely, labelled by the Encyclopædia Britannica as being 'among the first works of its kind' ${ }^{\prime 15}$ Van Doren proudly described it as 'an anthology of the world's best poetry in the best English [he] could unearth'. ${ }^{16}$ Black Marigolds occupies almost half of the slim Sanskrit section, which runs between pages 52 and 79 of the 1274-page anthology. In fact, Powys Mathers' non-scholarly, second-hand lyric versions - not only from Sanskrit, but also from Chinese, Japanese and Arabic - abound in Van Doren's anthology. The pervasiveness of Powys Mathers' 'translations' in the first Anthology of World Poetry attests to the canonization of a hybrid type of Eastern-Western poetry: this lyric subgenre, the product of creative contamination between different sources and languages, was presented to the Western public as an easily digestible and enjoyable fragment of the 'world's best poetry'.

In the case of Black Marigolds, this process of canonization started from a position of relative obscurity of both the translator and the original poem (which was, of course, far from obscure across South Asia); this state of affairs is captured by the questions that Carnevali asked at the beginning of his review: 'Whoever thought of Sanskrit? Whoever heard of Chauras? And who is E. Powys Mathers?' The same questions have been posed by generations of readers of Black Marigolds; it is a compelling paradox that the poem itself provides no answer to them: like a hall of mirrors, it tantalises and frustrates its readers' curiosity, without revealing much about its original intention or process of composition. 
Black Marigolds is - as we shall see - a chant on love, death and the ineluctability of fate. Yet it is also a poem on the ambiguous nature of the process of translation, which endlessly pushes us to ask: What is being translated, and by whom? The very title Black Marigolds, having no relationship with the Sanskrit Caurapañcāśikā, appears as a riddle. Its puzzling nature was further enhanced in Van Doren's 1928 anthology, where the poem appeared without the epigraph from which the titular phrase had been extracted. In contrast, the 1919 edition of Black Marigolds effectively opened with a quote attributed to Azeddine el Mocadecci: 'And sometimes we look to the end of the tale that there should be marriage-feasts, and find only, as it were, black marigolds and a silence.'

It is likely that Powys Mathers lifted the name of the Arab author - with this particular Westernized spelling - from Richard Francis Burton's introduction to his second-hand translation of an Arabic-language sex manual, The Perfumed Garden of the Cheikh Nefzaoui; ${ }^{17}$ the quotation that Powys Mathers ascribes to the Arab author is almost certainly a forgery. The faux-Arabic verse reads like an epitome of the poem Black Marigolds: indeed, at 'the end of the tale' of Chauras ${ }^{18}$ and Vidya - the poet and his beloved - there are no 'marriage-feasts', but only mournful 'black marigolds' and the 'silence' of death. Through Azeddine el Mocadecci's verse, Powys Mathers gestures to the cultural and linguistic multilayered-ness of Black Marigolds - the Anglo-French-Sanskrit poem that owes its title to a pseudo-Arabic verse, where the poets Bilhana and Azeddine el Mocadecci seem to find a space for dialogue and mutual translation. 
Except that, of course, these deeply intertextual 'black marigolds' are the product of the English translator's literary fancy. There is no Arabic original behind the poem's epigraph; and Black Marigolds itself is partly a second-hand translation from the French, partly - as the author openly states - an 'interpretation', which is often so free as to be utterly incomparable to the original Caurapañcassiki an. One may be rightly tempted to interpret Powys Mathers' 'fake multilingualism' as the ultimate mockery of the translation enterprise; instead, I read it as an oblique way to celebrate tacit border crossing between literary imaginaries and the creative possibilities offered by poetic hybridity and linguistic masquerade.

In Powys Mathers' prefatory remarks - which do not appear in Van Doren's anthology - Black Marigolds is said to be 'an interpretation rather than... a translation of [Chauras'] work; an attempt to bring over into an English poem the spirit of mournful exaltation which informs his Sanskrit leave-taking ${ }^{\prime}{ }^{19}$ In the same preface, Powys Mathers claims that 'the poem... has verses of direct, almost literal translation' ${ }^{20}$ It is precisely in those verses that Powys Mathers' vocabulary and syntax acquire an un-English texture, thus subtly hinting at the foreign-ness of the original: not Bilhana's Sanskrit poem, but Hippolyte Fauche's 1852 French translation. Yet, to the best of my knowledge, Black Marigolds has never been explicitly connected with Fauche's translation. In his preface to the poem, Powys Mathers does not discuss his sources but leaves a few (misleading) clues that pointed to Edwin Arnold's 1896 versified English translation, An Indian Love-Lament. 
Such clues were picked up and eloquently elaborated upon by the poet and translator Tony Harrison, who claimed that Powys Mathers 'probably had to make use of a previous translation of the Chaurapanchasika by Sir Edwin Arnold who did know Sanskrit'.21 This imagined connection between Black Marigolds and Arnold's An Indian Love-Lament lies behind the orange-coloured flower represented on the cover of the 2004 Anvil Press reprint of Black Marigolds, which includes Harrison's essay. The cover image is Arnold's watercolour drawing of (possibly) a campaka flower with a bee in the centre; it originally appeared next to stanza 35 in the lithographed edition of An Indian Love-Lament. Arnold's orange flower - extracted from its original context and re-purposed as an illustration on the front cover of a reprint of Black Marigolds - imperceptibly metamorphoses into what it is not: a black marigold.

Powys Mathers would not have probably objected to this attempt to make the boundaries between Black Marigolds and other versions of the Caurapañcāsikiā even more blurred and porous. Yet there is something paradoxical about the assimilation - and figurative conflation through the campaka flower - of Powys Mathers' and Arnold's translations: for the two versions are characterized by markedly divergent choices in terms of both style and content, while neither of them is directly based on a Sanskrit original. ${ }^{22}$ The common denominator of the two 'translations' is their will to project onto the Caurapañcāsikā notions and idioms of lyrical poetry that were fashionable in the West at the time of their composition. Albeit through different rhetorical means, Arnold and 
Powys Mathers effectively counteracted the lack of 'elevation of sentiment' and 'simplicity of diction' that Colebrooke chastised in his essay on Sanskrit poetry. At the same time, they both positioned themselves into a specific literary niche - that of 'Oriental' or 'Eastern' love poetry in translation - whose popularity, vitality and portability remain unchanged a hundred years later.

Despite (or perhaps because) it is rhetorically distant from both its immediate Anglophone predecessor and its Sanskrit source, the first stanza of Black Marigolds still enjoys a moderate yet steady fame. It can be found quoted online in blog-posts and forums, as well as published essays, poetic anthologies and works of fiction.

\section{Even now}

My thought is all of this gold-tinted king's daughter

With garlands tissue and golden buds,

Smoke tangles of her hair, and sleeping or waking

Feet trembling in love, full of pale languor;

My thought is clinging as to a lost learning

Slipped down out of the minds of men,

Labouring to bring her back into my soul. ${ }^{23}$ 
Powys Mathers' verse is infused with a subtle and slightly enigmatic sensuality, whereas in the case in the Sanskrit verse, the reader is left to imagine the circumstances in which the poetic voice finds himself. Arnold, instead, begins his translation with a reference to the imminence of the poetic I's death, thus obliterating the 'adyāpi' ('even now') anaphoric refrain of the original, which Powys Mathers preserved. Another conspicuous omission in Arnold's translation is the simile that juxtaposes the beloved to 'knowledge' (or 'science', or even 'incantation') 'lost in madness' ('vidyāṃ pramādagalitām').

I am to die! yet, I remember, dying,

My soul's delight - my sweet unequalled, love,

Like a fresh champak's golden blossom lying,

Her smile its opening leaves; and, bright above,

Over her sleepful brow those lustrous tresses

Dark-winding down, tangled with love's caresses..$^{24}$

The formal and stylistic choices made by Powys Mathers and Arnold could not be more divergent. Arnold rendered Bilhana's stanzas as sesta rima verses, each consisting of a quatrain followed by a couplet; the lines are iambic pentameters and rhyme according to the scheme ABABCC. Arnold's metrical experiment was an unprecedented attempt to turn 
the Caurapañcassikā into a text that would not read as a literal prose rendering, but as a free interpretation that showcased the formal and stylistic features of an English poem. The operation of recasting the Caurapañcāsikea according to modern poetic conventions also characterises Black Marigolds, though Powys Mathers opted for a less traditional format of free verse stanzas made up of seven or eight lines.

Not only does Black Marigolds represent a marked departure from Arnold's metric scheme, it is also independent from An Indian Love-Lament in terms of content and diction. This becomes perfectly clear if we read through the last sentence of Powys Mathers' verse: 'My thought is clinging as to a lost learning / Slipped down out of the minds of men, / Labouring to bring her back into my soul'. These lines find no counterpart in Arnold's stanza. They are, in fact, an amplified translation of Fauche's rendering of 'vidyāṃ pramādagalitām', 'knowledge lost in madness': 'ma pensée, dis-je, est sur elle, comme sur une science, échappée faute de soin, et qu'on s'applique à ramener dans son esprit' ('my thought, I say, is upon her, as on a science slipped away due to lack of care, and which one tries to bring back into one's soul'). The phrases that Fauche emphasizes in italics are ones which he inserted with the intention of clarifying or improving the readability of the text. To quote Fauche's first stanza in its entirety:

À cette heure même, ma pensée est toute à cette fille de roi, au teint doré, aux guirlandes tissues avec le tchampaka à fleurs d'or, - au 
visage de lotus épanoui, aux touffes soyeuses de cheveux, - aux membres agités par l'amour, soit qu'elle dorme ou qu'elle veille, et tout remplis d'une voluptueuse langueur : - ma pensée, dis-je, est sur elle, comme sur une science, échappée faute de soin, et qu'on s'applique à ramener dans son esprit. ${ }^{25}$

(At this very hour, my thought is all with this king's daughter, with a golden tint, with garlands woven with the tchampaka with golden flowers, - with a full-blooming lotus face, with silky tufts of hair, with limbs agitated by love, whether she sleeps or is awake, and filled with a voluptuous languor: - my thought, I say, is upon her, as on a science slipped away due to lack of care, and which one tries to bring back into one's soul.)

We might describe Powys Mathers' translation as displaying an attitude of devotion towards the lexical and phonetic texture of Fauche's text. For example, he did not refrain from translating even the phrases that Fauche signalled as being his own additions; thus, in the second line of the stanza, Powys Mathers writes 'My thought is all of this goldtinted king's daughter', which corresponds verbatim to Fauche's 'ma pensée est toute à cette fille de roi, au teint doré' ('my thought is all with this king's daughter, with a golden 
tint'). Powys Mathers even rendered 'ma pensée est toute' literally as 'my thought is all', whereas in English the plural 'my thoughts' would have sounded more natural. In fact, sometimes Powys Mathers mirrored and 'mimicked' his French source to the point of rendering his own English diction slightly dissonant and estranging. Consider, for example, the line: 'With garlands tissue and golden buds', a phonetic rendering of 'guirlandes tissues' ('aux guirlandes tissues avec le tchampaka à fleurs d'or', 'with garlands woven with the tchampaka with golden flowers'). Interestingly, Powys Mathers lifted the phrase 'guirlandes tissues' / 'garlands tissue', however nonsensical it may sound in English, but rejected the Sanskrit term 'tchampaka'. Again, Powys Mathers' diction reveals the French rather than the Sanskrit source in watermark.

Let us return, at this point, to the two translational categories outlined by Powys Mathers - 'direct, almost literal translation' and 'free interpretation'. In which of these two categories would the first stanza of Black Marigolds fall? So far, we have been able to appreciate the conspicuous literalness of Powys Mathers' translation from the French. However, even in this remarkably 'faithful' verse there are details that signal the presence of Powys Mathers not merely as a translator, but as a poet. An expression that does not find an exact equivalent in the French source is: 'Smoke tangles of her hair', which poetically paraphrases 'aux touffes soyeuses de cheveux' ('with silky tufts of hair'). A similar expression - almost a Mathersian poetic seal - appears in stanza 35: 'And curving hair, subtle as a smoke'. 
Furthermore, Black Marigolds is pervaded by depictions of the princess's feet, which instead are mentioned only in passing in the Sanskrit poem and in Fauche's translation. In the first stanza, Fauche's 'aux membres agités par l'amour' ('with limbs agitated by love') is substituted with '[f]eet trembling in love'. Feet acquire almost a fetishistic importance in Powys Mathers' lyrical landscape; another outstanding example is the second half of stanza 38, which is occupied by an image that finds an almost exact equivalent in the French and in the Sanskrit text - were it not for the spurious detail of the woman's 'scented feet', which is a purely Mathersian addition: 'I am not certain but that dark Brahma / In his high secret purposes / Has sent my soft girl down to make the three worlds mad / With capering about her scented feet'. Both these descriptive details - the comparison of the woman's hair with smoke and the obsessive references to her feet - are symptomatic of an attempt to partly overwrite the texture of the (French) original and tinge it with Powys Mathers' own erotic sensitivity.

MODERN EMOTIONAL LANDSCAPES: LOVE AND DEATH IN BLACK

\section{MARIGOLDS}

What emerged from the details of form and content analysed in the previous paragraph was the hybrid nature of Powys Mathers' poem, where the French source and the English 
poet's original voice alternate in a multilingual polyphony. As I will show in this section, Powys Mathers' deviations from Fauche's model become more radical and conspicuous in correspondence with the most erotically explicit stanzas of the Caurapañcassikā. The lyrical eroticism of the original - which Fauche generally preserved in his version - was effectively overwritten by Powys Mathers' idiosyncratic and often mystifying emotional landscapes. This is particularly evident in stanza 48, which reads:

Even now

I mind that I went round with men and women,

And underneath their brows, deep in their eyes,

I saw their souls, which go slipping aside

In swarms before the pleasure of my mind;

The world was like a flight of birds, shadow or flame

Which I saw pass above the engraven hills.

Yet was there never one like to my woman.

Were it not for the slightly un-grammatical last line of the stanza ('Yet was there never one like to my woman'), it would be hard to find a connection between the narrative thread of Black Marigolds - however tenuous - and the series of images that follow, 
overlap, and cancel each other in these lines, as if through the free associations of an interior monologue. Powys Mathers' stanza 'corresponds' - although only from the point of view of its position within the poem - to the following Sanskrit verse:

adyāpi tat suratakelinirastrayuddham

bandhopabandhapatanotthitaśūnyahastam I

dantaușṭhapīḍananakhakṣataraktasiktam

tasyāḥ smarāmi ratibandhuraniṣțhuratvam | |48| |

(Even today, I remember that battle without arms of love-play, [fought] with empty hands - joining and disjoining, falling and rising -, sprinkled with blood from the pressing of lips with teeth and the wounds [inflicted by] nails, with her charming roughness in making love.)

Fauche rendered the love-making scene with philological exactitude:

À cette heure même, ces jeux de l'hymen aux combats sans armes, - aux mains vides, qui se lèvent et retombent, qui enlacent et sont 
enlacées, - où le sang, dont elles sont arrosées, n'est que celui des blessures faites par les ongles et des lèvres dévastées par les dents; - je me les rappelle, avec sa fureur inégale dans les grandes batailles de la volupté.

(At this very hour, these hymeneal [i.e. 'marital'] games [characterized by] unarmed fights, - by empty hands, which rise and fall, which clasp and are clasped, - where the blood, with which they are sprinkled, is but that of the wounds made by nails and of lips ravaged by teeth; - I remember them, with her rough fury in the great battles of voluptuousness.)

In general, Powys Mathers tended to obfuscate the eroticism of the Caurapañcāśikā, either overwriting a love-making scene with a stream of consciousness - as is the case of the stanza that we have just examined - or interspersing the literal translation of Fauche's text with strategic translational silences. Thus, Powys Mathers' rendering of the scene of 'viparìtarata' ('inverted intercourse', i.e. intercourse where the woman lies on top) does contain some of the images of the French source; however, these images are extracted from their original context and their erotic import is diluted. Fauche's own rendering of the compound 'viparītaratābhiyoge' ('in the effort of inverted intercourse') in stanza 12 
is slightly convoluted and opaque: 'par l'agitation d'une attitude inverse dans l'assaut de volupté' ('by the restless movement of a reversed position in the assault of sensual pleasure'). Yet, in spite of his euphemistic allusion to intercourse, Fauche did not obscure the erotic quality of the scene depicted by Bilhana. In contrast, Powys Mathers glosses over the love-making and focuses on the detail of the earrings tapping against the beloved's cheeks - a detail that is emptied of any specific erotic significance: 'O golden rings / That tap against cheeks of small magnolia leaves'. This phrase corresponds - with the addition of the quasi-Sanskritic identification between 'cheeks' and 'small magnolia leaves' - to Fauche's 'aux joues battues par ses anneaux d'or' ('with cheeks beaten by her golden rings'). ${ }^{26}$ Instead of alluding to the kind of movement that had set the earrings in motion, the poetic persona of Black Marigolds addresses the beloved's cheeks with melancholic rather than graphically erotic overtones: ' $\mathrm{O}$ whitest so soft parchment where / My poor divorced lips have written excellent / Stanzas of kisses, and will write no more'.

Although, as shown by the above examples, Powys Mathers refrains from rendering the more explicitly erotic passages of Fauche's version, sex is not altogether absent in Black Marigolds. Yet, paradoxically, the only explicit reference to love-making is not centred around the poetic persona's beloved. Instead, the Sanskritic-sounding, yet genuinely Mathersian characters of 'the priestesses of Rati' are thus described in stanza 37: 'I have seen the priestesses of Rati make love at moon-fall / And then in a carpeted hall with a bright gold lamp / Lie down carelessly anywhere to sleep.' It is not 
coincidental, I believe, that this scene is - at the same time - explicitly erotic and intensely exotic. In fact, the mention of the goddess Rati is one of the very few references to Indian culture in the poem, which Powys Mathers had probably lifted from stanza 30 of Fauche's translation. In Black Marigolds, the 'exotic erotic' finds its poetic incarnation in the nocturnal love-making of the priestesses of Rati, and then in their sleeping 'in a carpeted hall with a bright gold lamp'. This imaginary landscape is only vaguely reminiscent of the 'palais blanc' ('white palace') described by Fauche in stanza 18: it is, indeed, a fully Mathersian landscape, where eroticism, the exotic, and poetic freedom achieve a unique harmony.

The entirely idiosyncratic handling of the erotic element in Black Marigolds has not failed to puzzle (and even polarize) literary critics throughout the century-long history of the poem's reception. At one end of the spectrum is the perception of Black Marigolds as 'super-sultry', as the poem was appreciatively described in 1999 by the Scottish poet and translator Edwin Morgan. ${ }^{27}$ This starkly contrasts with what the Polish Sanskritist Halina Marlewicz wrote roughly a decade later: for she claimed that Black Marigolds is a celebration of 'the 'spiritual (for lack of a better word) side' of love'. ${ }^{28}$

The critic who seems to strike a good balance between these two extremes is the English poet and translator Tony Harrison, who - as a great admirer of Powys Mathers wrote the introduction to a 2004 reprint of Black Marigolds and Coloured Stars. While he did not deny the strongly sensual dimension of the poem, Harrison suggested that we 
read it - like Ezra Pound's Cathay - as a literary work marked by the experience of war: for 'Mathers' Even now allows us to hear the passing bells of World War One tolling behind a passionate sensual recall' ${ }^{29}$ This reading of Black Marigolds finds its roots in a biographical detail that Powys Mathers shared in his preface, where he recalled: 'My rendering was finished in 1915, in two or three sessions on a box by the stove in hutments; and I have not cared to risk a discrepancy of moods in more luxurious minutes and places'.$^{30}$ Following Powys Mathers' autobiographical notes and Harrison's interpretive suggestions, we can indeed read Black Marigolds not simply as the modern translation (and partial re-writing) of an ancient love-song, but also as the lyrical outpouring of a man living away from home and severed from his loved ones.

Harrison's biographical reading of Black Marigolds is original and refreshing, because it shifts the critical focus from the often rehashed tropes of Orientalist critique (where the translation of an Oriental text always risks to be too easily essentialized as a product of cultural appropriation, manipulation and power assertion) and invites us instead to look at the poem as the expression of a subjective and contextual state of being. Harrison interprets Black Marigolds as subtly fraught with the feeling of precariousness that derives from the experience of living in war times - a feeling of precariousness that finds a paradoxical, yet profoundly human consonance with the erotic themes and tones that run through the poem. 
Bilhana's poem is, indeed, constantly balancing between the two antithetical yet not heterogenous poles of love and death. In Arnold's An Indian Love-Lament, the theme of the imminence of death is pervasive, and - to an extent - the same can be said of Black Marigolds. Yet, Powys Mathers' handling of the death theme differs from Arnold's. For Black Marigolds ends with a feeling of serene acceptance that the end is near: in the last stanza of the poem, the poetic I blends melancholy and nostalgia with a welcoming of death, towards which he advances 'as to a gala day'.

\author{
Even now \\ I know that I have savoured the hot taste of life \\ Lifting green cups and gold at the great feast. \\ Just for a small and a forgotten time \\ I have had full in my eyes from off my girl \\ The whitest pouring of eternal light. \\ The heavy knife. As to a gala day.
}

The poetic I in Black Marigolds, though perceiving the closeness of 'the heavy knife', ${ }^{31}$ focuses his thoughts on 'the hot taste of life' that he has been able to savour, 'lifting green cups and gold at the great feast'. Remarkably, in this last stanza it is not only life to be 
remembered as a 'great feast': for death is, too, a 'gala day' towards which the prisoner advances. The death-sentenced poetic persona is aware that he has already been able to enjoy, 'just for a small and a forgotten time', 'the whitest pouring of eternal light' emanating from his 'girl'. Thus, the 'girl' of Black Marigolds transfigures into a salvific figure, whose super-human nature is frequently alluded to in the poem. This suggestion is particularly strong in stanzas 16 and 18 , where she appears to the poetic I as he is secluded in his cell: 'I seem to see my prison walls breaking / And then a light, and in that light a girl' (stanza 16); 'I seem to see my prison walls come close, / Built up of darkness, and against that darkness / A girl no taller than my breast and very tired' (stanza 17).

In these verses, the girl is always associated with light, which contrasts with the darkness of the prison cell; similarly, in the last stanza Powys Mathers describes an 'eternal' light pouring from his girl. It is perhaps this forever-shining light that gives the poetic I the strength to face death, which is also - crucially - a liberation and final escape from the darkness of the prison cell. 'Even now / Death I take up as consolation': such is the beginning of the penultimate stanza of the poem. This sentiment does not find an exact counterpart in Bilhaṇa's poem, nor in Fauche's translation of stanza 49:32 in fact, I believe that such a stance towards death - welcomed as a 'consolation' (not simply as the cessation of love's torment) and as 'a gala day', or a day of rejoicing - is the most innovative, though generally unacknowledged, turn that Powys Mathers took in his 'translation' of the Caurapañcāsiikā. 
Such an innovative take can be best appreciated if we compare the last stanza of Black Marigolds with the corresponding verse in the Sanskrit poem. Here no mention is made of the princess, nor of the poet's imminent execution. Instead, three mythological figures -Śiva, Viṣnu in the shape of his tortoise avatāra, and the ocean - epitomize the consistence, steadiness and faithfulness that the poet hopes his executioner will show by killing him quickly ${ }^{33}$ (or, perhaps, that the poet himself will show, expiating his love for the princess through his death). ${ }^{34}$

adyāpi nojjhati haraḥ kila kālakūṭaṃ

kūrmo bibharti dharaṇị̄ khalu prșțhakena I

ambhonidhir vahati duḥsahabāḍavāgnim an̉gīkṛtam sukṛtinah paripālayanti | |50| |

(Even today, certainly Śiva does not release the poison, certainly the turtle carries the earth on its back, [and] the ocean retains the unrestrainable submarine fire. The noble-minded keep their promises.) 


\section{CONCLUSIONS: THE AFTERLIFE OF A SANSKRIT POEM}

The portentous spectacle that artistic Asia offers [...] would be made more magnificent by the advent of two little books by E. Powys Mathers, would-be translations of folk-songs and ancient and modern poems of Asia, love songs mostly, if... there is an if: if said poems and songs were actually of ancient and modern Asia, and not, as some scholars assure us, more or less faked. But Mr. Mathers is not just a faker, he is a poet, as the following, whether a translation or not, bears witness $[\ldots] .35$

Once again, Carnevali's words effectively capture the feelings that readers of Black Marigolds have expressed from the time of its publication until its dissemination on the Web. The recognition of the intrinsic value of Powys Mathers' verses as lyric poetry allowed literary critics to bypass the issue of the author's paradoxical status as secondhand translator and trans-creator. Van Doren's World Poetry anthology attests to the same sentiment of unquestioning appreciation for Powys Mathers' verses, be they second-hand translations - or even pseudo-translations - of Sanskrit, Chinese, Japanese or Arabic 'lyrics'.

Yet Powys Mathers was not merely appropriating and (at least partly) overwriting ' $[\mathrm{t}]$ he portentous spectacle [of] artistic Asia' for a Western audience: a testimony of this is 
the existence of re-translations into South Asian languages of the English poet's verses. The Sri Lankan poet Mimana Premathilaka (1918-65) published 'Sinhala translations of E. Powys Mathers's Coloured Stars: Fifty Asiatic Love Lyrics' ${ }^{36}$ The Urdu poet Mīrājī (191249) translated select verses of Black Marigolds, which he published under the title 'Kāle Gende' ('Black Marigolds'); ${ }^{37}$ moreover, Mīrājī translated into Urdu numerous sections from Powys Mathers' Eastern Love volumes (1927-30), which are discussed by Orsini in the present volume.

After its inclusion in Van Doren's Anthology of World Poetry, Black Marigolds was injected with a new literary significance when American Nobel laureate John Steinbeck (1902-1968) quoted it extensively in his 1945 novel Cannery Row (chapters 30 and 32). ${ }^{38}$ In Cannery Row, the stanzas of Black Marigolds - devoid of any connection to 'Vidya', 'Chauras', Bilhana or Powys Mathers - become embedded in the emotional texture of Steinbeck's novel: twice the novel's protagonist, Doc, stumbles upon an unspecified book from which he reads out seemingly random verses which, in fact, belong to Black Marigolds. Cannery Row proved even more effective than Van Doren's anthology in sparking the curiosity of generations of readers not only for Black Marigolds, but also for a specific (if inauthentic and largely fabricated) genre of 'exotic erotic' lyric poetry.

As I showed in my paper, a hybrid translation like Black Marigolds cannot simply be interpreted and assessed on the basis of its faithfulness to an 'original', but it rather has to be read as a text that possesses multiple levels of meaning, which appear as if in 
watermark. Just as I take seriously the genealogical aspect of this second-hand-cumpseudo-translation, so I do not underestimate its impact both as a vector of transmission of the original text and as an independent work of art - which, like a hall of mirrors, reflects and multiplies the textual meanings and emotional shades of its various (direct and indirect) sources.

Nowadays, one can listen to the reading of a selection of stanzas of Black Marigolds on YouTube, ${ }^{39}$ the caption of the video boldly claims that Powys Mathers' translation has been '[s]ometimes called the world's greatest love poem'.$^{40}$ What is even more thoughtprovoking, a YouTube user, Ahavati1, thus commented on the video: 'It was this poem which led me eastward to Rumi and the other mystics of words and God' ${ }^{41}$

It should not surprise us that Black Marigolds may be perceived by different contemporary readers as 'the world's greatest love poem' as well as a stimulus to travel 'eastward' (if only literarily and spiritually) to discover Rumi, the famous thirteencentury Persian poet and Sufi mystic. This protean and vital force is a result of Powys Mathers' idiosyncratic approach to the process of translation. For Black Marigolds did not seek to transcend, but rather embraced the contrasting feelings of familiarity and estrangement that Colebrooke expressed in his seminal essay on Sanskrit erotic poetry. Thus, Powys Mathers faithfully translated - from the French - those images and expressions where Western readers would recognize both themselves and their notions of lyric poetry. On the other hand, he sublimated the 'exotic erotic' elements of the 
original into a lyric stream of consciousness - a seemingly disjointed and sometimes grammatically questionable sequence of 'borrowed' and original images, emotional outpours, and quasi-hallucinatory visions - which blends modern sensuousness with a reflection on the universal inevitability of death and loss.

${ }^{1}$ Henry Thomas Colebrooke, 'On Sanscrit and Pracrit Poetry', Asiatick Researches, 10 (1808), 389-474 (p. 419).

2 Siegfried Lienhard, A History of Classical Poetry: Sanskrit-Pali-Prakrit, in History of Indian Literature, edited by Jan Gonda, 10 vols (Wiesbaden: Harrassowitz, 1984), III.1, 92.

3 Love Lyrics by Ámaru \& Bhartri-hari, translated by Greg Bailey; \& by Bilhaṇa, edited and translated by Richard Gombrich (New York: New York University Press \& JJC Foundation, 2005).

${ }^{4}$ Powys Mathers was as prolific as he was - and still is - elusive; the biographical monograph which has been recently completed by Jeffrey Talmadge (of Austin, Texas) will be the first fullfledged study to shed light on this author's life and personality.

${ }^{5}$ Edward Powys Mathers, English Versions \& Terminal Essays (1930), in Eastern Love, 12 vols (London: John Rodker for subscribers, 1927-30), XII, 91.

${ }^{6}$ Edward Powys Mathers, The Loves of Rādhā and Krishna and Amores. English versions from the Bengali of Chandīdāsa, and from the Sanskrit of Amaru and Mayūra (1928), in Eastern Love, 12 vols (London: John Rodker for subscribers, 1927-30), V, 139.

${ }^{7}$ Included in volume V of Eastern Love. 
${ }^{8}$ Maddalena Italia, ‘Translation Immoral? Contamination, Hybridity, and Vociferous Silences in Early Twentieth-Century Translations of Sanskrit Erotic Poetry', Sanglap: Journal of Literary and Cultural Inquiry, 5.1 (September 2018), 7-21.

${ }^{9}$ Edward Powys Mathers, Black Marigolds: Being a Rendering into English of the 'Panchasika of Chauras' (Oxford: B.H. Blackwell, 1919).

${ }^{10}$ See Barbara Stoler Miller, Phantasies of a Love Thief: The Caurapañcāśikā attributed to Bilhaṇa (New York: Columbia University Press 1971).

${ }^{11}$ Hippolyte Fauche, Bhartrihari et Tchaaura, ou La pantchaçika du second et les sentences érotiques, morales et ascétiques du premier. Expliquées du sanscrit en français, pour la première fois, par Hippolyte Fauche (Paris: A. Frank, 1852).

12 Edwin Arnold, The Chaurapanchâsika: An Indian Love-Lament (London: K. Paul, Trench, Trübner \& Co, 1896).

${ }^{13}$ Emanuel Carnevali, 'Two Books of Refuge', Poetry, 18.1 (1921), 46-48 (p. 46).

14 Edwin Morgan, 'World Poetry: An Anthology of Verse from Antiquity to Our Time' (review), Translation and Literature, 8.2 (1999), 273-276 (p. 273).

${ }^{15}$ Encyclopædia Britannica, 'Mark Van Doren', < https://www.britannica.com/biography/Mark$\underline{\text { Van-Doren> }}$ [accessed 15 April 2018].

${ }^{16}$ Mark Van Doren, An Anthology of World Poetry (New York: The Literary Guild of America, 1928), p. viii.

17 'Azeddine el Mocadecci' is mentioned by Burton in his 'Notes of the Translator' to The 
Perfumed Garden of the Cheikh Nefzaoui, a fifteenth century Arabic-language manual on erotology. Discussing the sources of The Perfumed Garden, Burton stated that, 'the book "Birds and Flowers", by Azeddine el Mocadecci, seems to have been consulted with respect to the interpretation of dreams' (p. xii). See Richard Francis Burton, The Perfumed Garden of the Cheikh Nefzaoui: A Manual of Arabian Erotology, revised and corrected translation (Cosmopoli: Kama Shastra Society of London and Benares, and for Private circulation only, 1886).

${ }^{18}$ Here I follow Powys Mathers' spelling.

${ }^{19}$ Edward Powys Mathers, Black Marigolds and Coloured Stars (London: Anvil Press Poetry, 2004), p. 85.

${ }^{20}$ Ibid.

${ }^{21}$ Tony Harrison, 'Introduction', in Black Marigolds and Coloured Stars by Edward Powys Mathers (London: Anvil Press Poetry, 2004), p. 9. In fact, I believe that Arnold's very loose translation of the Caurapañcāśikā (which even contains a fake-Sanskrit quotation) is entirely based on Peter von Bohlen's 1833 Latin version of the poem. See Peter von Bohlen, Bhartriharis sententiae et carmen quod Chauri nomine circumfertur eroticum (Berlin: Dümmler, 1833).

${ }^{22}$ See my note above.

${ }^{23}$ Black Marigolds, v. 1.

${ }^{24}$ An Indian Love-Lament, v. 1.

25 La pantchaçika, v. 1. In Bohlen's Bhartriharis sententiae et carmen quod Chauri nomine circumfertur eroticum (the edition of the Sanskrit text that Fauche translated), the first verse of the 
Caurapañcāśikā reads as follows: “adyāpi tām kanakacampakadāmagaurīm phullāravindavadanāṃ tanuromarājīm | suptotthitāṃ madanavihvalasālasāngīṃ vidyāṃ pramādagalitām iva cintayāmi I|" (“Even today I think of her, golden [or 'bright'] with [or 'as'] a garland of golden campaka flowers, with a thin line of hair above her navel, with her face [or 'mouth'] like a full-blown lotus, risen from sleep, with her limbs languid, stirred by love, like knowledge lost in madness."). Unless otherwise stated, all translations from Sanskrit and French are my own.

${ }^{26}$ In the Sanskrit text, 'kanakakuṇụalaghṛșțagaṇạam' ('with her cheeks rubbed by the golden earrings').

${ }^{27}$ Morgan, review of World Poetry, p. 273.

${ }^{28}$ Halina Marlewicz, Złodziej Miłości, 50 wierszy. Wstęp, opracowanie, przekład, edycja tekstu H. Marlewicz (Krakow: Literatura indyjska, t. 3. Księgarnia Akademicka, 2008), p. 51.

${ }^{29}$ Harrison, 'Introduction', p. 11.

${ }^{30}$ Powys Mathers, Black Marigolds and Coloured Stars, p. 85. According to Harrison, Powys Mathers worked on his translation '[a]t one of the camps where he was billeted as assistant to the Medical Officer (either Woldingham, Halton or Northampton)' (p. 9).

${ }^{31}$ Powys Mathers probably imagined the detail of the 'heavy knife' when reading stanza 49 of Fauche's translation, which ends with the following words: 'ô toi, bourreau, tranche au plutôt ma vie!' ('o you, executioner, cut off my life quickly!').

32 The gist of this stanza is that the poetic I is incapable of living without enjoying intercourse 
(as Fauche explains in a footnote in Latin: 'Sine copulationis usu') with his beloved; hence, he hopes that his 'sorrows' may 'find peace in death'. Rather than a statement of serene welcoming of death, the French translation reads like the expression of a desperate urge to end the torments of love and lust through death.

${ }^{33}$ As Fauche interprets the verse.

${ }^{34}$ As Arnold's free rendering of the stanza suggests.

${ }^{35}$ Carnevali, 'Two Books of Refuge', pp. 346-347.

${ }^{36}$ Garrett Field, Modernizing Composition: Sinhala Song, Poetry and Politics in Twentieth-Century Sri Lanka, (Oakland, California: University of California Press, 2017), p. 67. I owe this reference to Jeff Talmadge.

${ }^{37}$ Mīrājī, Bāqiyāt-i Mìràjīe edited by Shīmā Majīd (Lahore: Pākistān Buks ainḍ Liṭrerī Sā' ūnḍz, 1990).

${ }^{38}$ John Steinbeck, Cannery Row (London; Toronto: William Heinemann Ltd, 1945).

$39<$ https://www.youtube.com/watch?v=2IgK-iYE9S4> published 14 December 2008 [accessed 17 February 2019].

${ }^{40}$ Ibid., post by SpokenVerse published 14 December 2008.

${ }^{41}$ Ibid., comment by Ahavati1 published in 2008. 